\title{
Aktivitas Antibakteri Isolat Bakteri Endofit Asal Daun Ciplukan (Physalis angulata L.) Terhadap Bakteri Escherichia coli dan Staphylococcus aureus
}

\section{Antibacterial Activity of Endophyte Bacteria Isolates From Ciplukan Leafs (Physalis angulata L.) Against to Escherichia coli and Staphylococcus aureus Bacteria}

\author{
Heni Setianah $^{1}$,*, Ika Afifah Nugraheni ${ }^{2}$, Doddy Sulistiawan Wibowo ${ }^{3}$ \\ 1,2,3 Universitas 'Aisyiyah Yogyakarta, Jalan Ring Road Barat No. 63 Nogotirto, Gamping, Sleman, Yogyakarta, 55292, \\ Indonesia \\ ${ }^{1}$ henisetianah997@gmail.com*, 2ikaafifah@unisayogya.ac.id, ${ }^{3}$ doddysw21@gmail.com \\ * corresponding author \\ Tanggal Submisi: . 12 Agustus 2020, Tanggal Penerimaan: 2 Desember 2020
}

\begin{abstract}
Abstrak
Tanaman ciplukan memiliki senyawa yang berpotensi sebagai antibakteri. Potensi senyawa antibakteri kemungkinan juga dimiliki oleh bakteri endofit. Penelitian ini bertujuan untuk mengisolasi bakteri endofit dari daun ciplukan sebagai antibakteri terhadap bakteri Escherichia coli dan Staphylococcus aureus. Metode penelitian meliputi isolasi bakteri endofit, karakterisasi morfologi, dan uji aktivitas antibakteri. Sebanyak 8 isolat bakteri endofit berhasil diisolasi dari daun ciplukan dan mampu menghambat pertumbuhan Staphylococcus aureus dengan diameter zona hambat berkisar antara 0,5-2 $\mathrm{mm}$ dan 2 isolat terhadap pertumbuhan Escherichia coli dengan diameter sebesar $2 \mathrm{~mm}$.
\end{abstract}

Kata kunci : Bakteri endofit; Daun ciplukan (Physalis angulata L.); Aktivitas antibakteri; Escherichia coli; Staphylococcus aureus.

\begin{abstract}
Ciplukan plants has compounds that have the potential as antibacterial. The potential of antibacterial compounds may also be possessed by the endophytic bacteria. This study aims to isolate endophyte bacteria from ciplukan leafs that have the potential as an antibacterial in against of Escherichia coli dan Staphylococcus aureus bacteria. The research method is isolation endophyte bacteria, morphological characterization, and antibacterial activity test. Eight isolates endophyte bacterial were successfully isolated from ciplukan leafs and were able to inhibit the growth of Staphylococcus aureus bacteria with inhibition zone diameters ranging from 0,5-2 $\mathrm{mm}$ and 2 isolates against the growth of Escherichia coli with a diameters of $2 \mathrm{~mm}$.
\end{abstract}

Keywords: Endophyte bacteria; Ciplukan leafs (Physalia angulata L.); Antibacterial activity; Escherichia coli; Staphylococcus aureus.

\section{PENDAHULUAN}

Indonesia merupakan negara yang terkenal dengan tanaman herbalnya. Tanaman herbal di Indonesia terdapat 2500 jenis yang banyak digunakan sebagai obat dalam pengobatan tradisional (Kemendag RI, 2014). Salah satu tanaman yang berpotensi sebagai obat herbal yaitu 
tanaman ciplukan (Physalis angulata L.). Potensi yang dimiliki tanaman ciplukan belum banyak diteliti dan dimanfaatkan oleh masyarakat. Hal tersebut dikarenakan tanaman ciplukan masih dianggap sebagai tanaman liar dan hama bagi tanaman budidaya.

Tanaman ciplukan adalah tanaman herbal tahunan yang memiliki tinggi sekitar 0,1-1 $\mathrm{m}$ dengan batang berwarna ungu dan hijau, berusuk bersegi tajam, berongga dan memiliki trikoma (Alkautsari dkk., 2015). Tanaman ciplukan memiliki akar tunggang, bercabang dan berserabut serta berwarna putih hingga kecoklatan dan intensif menyebar di permukaan tanah (Susilowati, 2017). Buah ciplukan dilindungi oleh kelopak hijau dan tulang kelopak berwarna ungu. Buah ciplukan berbentuk bulat dan berwarna kuning (Susilowati, 2017). Daun ciplukan memiliki ciri-ciri berwarna hijau, tulang daun menyirip, permukaan daun berambut, bentuk helaian daun bulat telur dengan ujung runcing, dengan panjang 5-12 cm dan lebar 4-7 cm, tipis, cepat layu, berbau langu serta bertepi rata atau bergelombang-bergerigi (Alkautsari dkk., 2015).

Secara umum, pemanfaatan tanaman ciplukan dikalangan masyarakat biasa digunakan dalam pengobatan tradisional. Daun ciplukan memiliki sifat analgetik dan detoksikan (Alkautsari dkk., 2015). Hal tersebut disebabkan adanya kandungan senyawa metabolit sekunder seperti saponin, flavonoid, alkaloid, tanin, glikosida dan steroid dalaam daun ciplukan (Alkautsari dkk., 2015). Secara umum, kandungan senyawa daun ciplukan dapat digunakan berpotensi sebagai antibakteri, antikanker, antitumor, dan antioksidan (Osho et al., 2010). Melihat banyaknya manfaat yang terdapat pada daun ciplukan, besar kemungkinan bakteri endofit yang terdapat pada daun ciplukan memiliki kemampuan dalam mensintesis senyawa yang sama seperti tanaman inangnya. Hal tersebut sesuai dengan penelitian Desriani dkk., (2014) yang menyatakan bahwa isolat bakteri endofit yang diperoleh dari tanaman binahong memiliki aktivitas antibakteri yang sama dengan tanaman inangnya.

Bakteri endofit adalah bakteri yang hidup di dalam jaringan tanaman dan bersimbiosis mutualisme dengan tanaman inang di mana bakteri endofit hidup di dalam jaringan tanaman dengan membentuk koloni senyawa metabolit sekunder tanpa membahayakan tanaman inang (Fithriya, 2015). Beberapa jenis bakteri endofit terdapat pada tanaman tingkat tinggi dan dapat menghasilkan senyawa metabolit sekunder yang sama dengan tanaman inang. Beberapa jenis bakteri endofit diketahui mampu menghasilkan senyawa metabolit sekunder yang sama dengan tanaman inangnya (Nursanti \& Suhartono, 2012). Senyawa metabolit sekunder yang dihasilkan dapat dimanfaatkan dalam bidang kesehatan maupun pertanian seperti antibakteri, antikanker, antifungi, antivirus, dan agen insektisida (Kusumawati dkk., 2014).

Senyawa bioaktif yang dihasilkan bakteri endofit mampu menghasilkan berbagai produk potensial, antara lain bakteri Pseudomonas viridiflava yang berasal dari rumput hias Grass mampu menghasilkan Ecomycins B dan C sebagai antibakteri. Selain itu, bakteri Streptomyces griseus dari tanaman mangrove Kandelia candel mampu menghasilkan asam $p$ aminoacetophenonic sebagai antibakteri. Bakteri Streptomyces NRRL 30562 dari bunga Kennedia nigriscans menghasilkan munumbisin sebagai antibiotik dan Streptomyces NRRL 30566 yang diperoleh dari bunga Grevilea pteridefolia mampu menghasilkan kakadumisin sebagai antibiotik (Miller et al., 1998; Guan et al., 2005; castilo et al., 2002 dalam Ryan et al., 2008). Selain itu, senyawa antibakteri yang dihasilkan dapat diaplikasikan sebagai antibiotik, biofertilizer dan biokontrol (Purwanto dkk., 2014 dan Sulistiyani \& Puspita, 2016).

Isolasi senyawa antibakteri dari bakteri maupun mikroba endofit dianggap lebih efisien dibandingkan dengan mengekstrak biomassa tanaman secara langsung (Kusumawati dkk., 2014). Pemanfaatan senyawa antibakteri dari ekstrak tanaman membutuhkan tanaman dalam jumlah yang banyak serta ketersediaan tanaman di lingkungan akan menurun. Senyawa antibakteri dapat diperoleh dari mikrobia endofit yang mampu menghasilkan sejumlah senyawa antibakteri yang dibutuhkan, sehingga tidak harus mengekstrak senyawa antibakteri dari tanaman inangnya (Simarmata dkk., 2007 dalam Kusumawati dkk., 2014). 
Penelitian-penelitian sebelumnya telah melakukan eksplorasi bakteri endofit dari tanaman herbal beserta uji aktivitasnya terhadap berbagai bakteri patogen. Berdasarkan penelitian Kusumawati dkk. (2014), sebanyak tiga isolat bakteri endofit yang diperoleh dari tanaman miana (Coleus scutellariodes L.) memiliki aktivitas antibakteri terhadap pertumbuhan bakteri Escherichia coli (E.coli) dengan diameter zona hambat $1 \mathrm{~mm}, 2 \mathrm{~mm}$ dan 3,3 mm. Lima belas isolat lainnya menunjukkan penghambatan terhadap $S$. aureus dengan diameter berkisar antara 1,5-7 mm (Kusumawati dkk., 2014). Purwanto dkk. (2014) menyatakan bahwa tiga isolat bakteri endofit dihasilkan dari tanaman sirih hijau (Piper betle L.) memiliki aktivitas antibakteri terhadap pertumbuhan bakteri Staphilococcus aureus (S. aureus) dengan diameter zona hambat $1 \mathrm{~mm}, 3 \mathrm{~mm}$, dan $5 \mathrm{~mm}$.

Sejauh ini, penelitian mengenai keberadaan bakteri endofit dari daun ciplukan beserta potensinya belum banyak dilakukan. Penelitian yang telah dilakukan hanya sebatas pada aktivitas antibakteri dari ekstrak daun ciplukan. Eksplorasi bakteri endofit dalam daun ciplukan sangat diperlukan untuk mengetahui keberagaman dan potensi plasma nutfah yang dimiliki Indonesia. Penelitian ini bertujuan untuk mengisolasi bakteri endofit dari daun ciplukan yang berpotensi sebagai antibakteri dalam menghambat pertumbuhan bakteri E. coli dan S. aureus. Bakteri endofit dari daun ciplukan diharapkan mempunyai aktivitas antibakteri terhadap ketiga bakteri patogen tersebut sehingga dapat dikembangkan sebagai penghasil antibakteri baru.

\section{METODE PENELITIAN}

\section{Subjek Penelitian}

Rancangan penelitian yang digunakan yaitu penelitian eksperimen. Penelitian dilakukan dengan mengisolasi bakteri endofit pada daun ciplukan dan mengetahui daya hambat bakteri endofit terhadap bakteri S. aureus, dan E. coli. Penelitian ini dilakukan di Laboratorium Mikrobiologi dan Imunologi, Universitas 'Aisyiyah Yogyakarta.

Pengambilan sampel daun ciplukan dilakukan pada tiga tanaman ciplukan yang tumbuh secara acak di lahan pertanian kacang-kacangan yaitu di Jalan Barak Gedhe, Dusun Margoluwih, Seyegan, Sleman, DIY. Pengkodean dilakukan sesuai dengan jumlah tanaman ciplukan dan dibawa ke Laboratorium Mikrobiologi dan Imunologi, Universitas 'Aisyiyah Yogyakarta untuk dilakukan pengujian.

\section{Alat dan Bahan}

Alat yang digunakan dalam penelitian ini adalah autoklaf, oven, petridis, tabung reaksi, gelas ukur, gelas beker, erlenmeyer, jarum ose, mikropipet, yellow tip, white tip, plastik wrap, pinset, drigalskispatel, tisu, kapas, aluminium foil, kertas saring, pelubang kertas, lampu bunsen, timbangan analitik, hotplate, penggaris, inkubator, dan lemari pendingin.

Bahan yang digunakan pada penelitian ini antara lain, daun ciplukan, Triptic Soy Agar (TSA), Triptic Soy Broth (TSB), kandistatin, natrium hipoklorit 5,25\%, etanol 70\%, kloramfenikol, aquades steril, bakteri patogen S. aureus, dan E. coli.

\section{Metode Penelitian \\ Isolasi Bakteri Endofit}

Daun ciplukan muda digunakan sebagai sumber bakteri endofit karena mengandung senyawa metabolit sekunder lebih banyak dibandingkan daun tua (Putri dkk., 2018). Sampel daun ciplukan dicuci dengan air mengalir hingga bersih untuk menghilangkan kotoran maupun organisme epifit. Daun ciplukan yang telah dicuci kemudian diambil masing-masing sebanyak dua buah dan dilakukan proses sterilisasi permukaan. Proses sterilisasi permukaan sampel dilakukan dengan merendam daun ke dalam larutan etanol 70\% selama 1 menit. Setelah itu, cairan perendam dibuang dan diganti dengan larutan Natrium hipoklorit 5,25\% lalu didiamkan selama 5 menit. Cairan perendam dibuang kembali dan sampel dibilas dengan etanol 70\% 
selama 1 menit lalu cairan perendam diganti dengan aquades steril selama 30 detik yang dilakukan selama 2 kali (Kumala \& Ainun, 2014).

Proses isolasi bakteri endofit mengikuti metode penelitian Purwanto dkk., (2014) dengan modifikasi. Daun ciplukan yang sudah steril dipotong menggunakan pisau steril sepanjang 1-2 cm dan ditumbuhkan dalam cawan petri yang berisi media TSA menggunakan pinset steril. Media TSA yang digunakan ditambahkan larutan kandistatin $(0,02 \% \mathrm{~b} / \mathrm{v}) 40 \mu \mathrm{l}$ sebagai antifungi. Proses penumbuhan daun ciplukan dilakukan dengan cara menekan daun hingga mengeluarkan cairan yang berada di dalam sampel. Daun ciplukan yang sudah ditumbuhkan kemudian diinkubasi pada suhu ruang selama 24-72 jam dan diamati jika terdapat koloni yang tumbuh.

\section{Pemurnian Bakteri Endofit}

Medium yang digunakan untuk pemurnian bakteri endofit yaitu medium TSA. Medium TSA yang digunakan untuk pemurnian ditambahkan larutan Kandistatin sebanyak 0,02\% b/v $(40 \mu 1)$. Bakteri endofit yang tumbuh pada medium TSA dimurnikan pada media padat dalam petridis dan media agar miring. Isolat bakteri diinkubasi pada suhu $25^{\circ} \mathrm{C}-28^{\circ} \mathrm{C}$ selama $24-72$ jam dan diamati morfologi koloni isolat bakteri endofit. Koloni yang memiliki warna, bentuk, tepian dan elevasi yang sama dianggap sebagai isolat yang sama (Wondal et al., 2019). Setiap koloni bakteri dipindahkan ke medium TSA dengan metode streak kuadran dan diinkubasi selama 24-72 jam. Isolat bakteri endofit disimpan pada media miring untuk digunakan sebagai stock kultur (kultur stok) (Nursulistyarini dkk., 2013).

\section{Karakterisasi Mofologi}

Karakterisasi morfologi isolat bakteri endofit yang telah diperoleh dapat diketahui berdasarkan beberapa kriteria antara lain, bentuk koloni berupa titik-titik, bulat, tidak beraturan, seperti akar, seperti kumparan dan berbenang. Selain itu, permukaan/elevasi koloni juga diamati berupa bentuk datar, naik, cembung, dan umbonatus. Kriteria lainnya yang menjadi acuan untuk mengetahui morfologi bakteri yaitu tepian koloni berupa tepian mulus, lobatus, bergelombang, bergerigi, dan filamentus. Warna koloni juga menjadi kriteria dalam menentukan morfologi bakteri yaitu dengan warna keputih-putihan, kelabu, kekuningkuningan atau hampir bening.

\section{Uji Aktivitas Antibakteri Terhadap Bakteri E.coli dan S.aureus}

Uji aktivitas antibakteri pada isolat bakteri endofit daun ciplukan dilakukan menggunakan metode Oktavia \& Sri, (2018) dengan modifikasi. Isolat bakteri endofit dan bakteri patogen di regenerasikan dalam medium TSA pada suhu $28^{\circ} \mathrm{C}$ selama $48 \mathrm{jam}$. Koloni bakteri endofit dan bakteri patogen yang berumur 48 jam dilakukan peremajaan pada medium TSB $50 \mathrm{ml}$ dan diinkubasi pada pada suhu $37^{\circ} \mathrm{C}$ selama 48 jam. Petridish yang berisi media TSA padat dibagi menjadi 4 bidang untuk 4 jenis isolat bakteri endofit. Sebanyak $100 \mu 1$ suspensi bakteri patogen dimasukan ke dalam cawan petri yang berisi media TSA dan diratakan menggunakan drigalskispatel. Sebanyak $25 \mu$ l isolat bakteri endofit diinokulasikan pada masing-masing kertas cakram. Pada penelitian ini, kloramfenikol $25 \mu$ l digunakan sebagai kontrol positif dan aquades steril $25 \mu \mathrm{l}$ sebagai kontrol negatif juga diinokulasikan pada kertas cakram. Isolat bakteri endofit selanjutnya diinkubasi pada suhu $37^{\circ} \mathrm{C}$ selama 24 jam. Zona hambat diamati setelah inkubasi 24 jam.

\section{Metode Pengumpulan dan Analisis Data}

Data diperoleh dengan cara mengumpulkan hasil pengujian yang dimulai dari data hasil isolasi bakteri endofit, pengamatan morfologi hingga data hasil uji aktivitas antibakteri terhadap bakteri patogen. Data hasil isolasi bakteri endofit digunakan untuk mengetahui isolat 
bakteri endofit yang diperoleh dari daun ciplukan. Data pengamatan morfologi bakteri endofit untuk mengetahui morfologi masing-masing bakteri endofit. Data uji aktivitas antibakteri untuk mengetahui zona hambat yang dihasilkan bakteri endofit terhadap bakteri patogen.

Analisis data dilakukan dengan melihat hasil ulangan pengujian aktivitas antibakteri pada masing masing isolat bakteri endofit. Data hasil pengujian aktivitas antibakteri yang diperoleh dianalisis dengan mencari rata-rata (mean) dari setiap ulangan pada setiap isolat kemudian dilihat nilai standar deviasi (SD) dari rerata masing-masing isolat.

\section{HASIL DAN PEMBAHASAN}

\section{Isolat Bakteri Endofit Daun Ciplukan}

Daun ciplukan digunakan sebagai sumber isolat bakteri endofit karena diketahui mengandung senyawa antibakteri. Daun ciplukan diperoleh dari 3 tanaman ciplukan (Gambar 1) yang berasal dari areal pertanian di Jalan Barak Gedhe, Dusun Margoluwih, Kecamatan Seyegan, Kabupaten Sleman, DIY. Penggunaan tiga tanaman ciplukan bertujuan untuk memperoleh keragaman jenis bakteri endofit yang berbeda pada ketiga tanaman ciplukan. Sampel daun ciplukan yang digunakan yaitu daun yang berumur muda. Hal tersebut dikarenakan daun muda memiliki kandungan senyawa metabolit sekunder yang tinggi dibandingkan dengan daun tua (Putri dkk., 2018). Menurut Irdawati dkk. (2017), tanaman dengan jenis yang sama memiliki kandungan bakteri endofit yang berbeda. Hal tersebut dipengaruhi oleh faktor biotik maupun abiotik (Amaria dkk., 2019). Bakteri endofit yang berasosiasi pada tanaman dipengaruhi oleh genotipe tanaman, umur tanaman dan bagian tanaman yang digunakan sebagai sumber bakteri endofit (Munif, 2012 dalam Amaria dkk., 2019). Bakteri endofit yang diperoleh pada bagian tanaman yang berbeda maka akan menghasilkan jenis bakteri endofit yang berbeda pula (Amaria dkk., 2019). Bakteri endofit hidup di dalam pembuluh vaskuler, bagian akar, batang, daun dan buah. Hal tersebut dikarenakan bakteri endofit masuk ke dalam jaringan tanaman melalui akar, bunga, batang, daun, kotiledon (Purwanto dkk., 2014) serta dengan melakukan penetrasi melalui luka dan stomata (Compant et al, 2010).
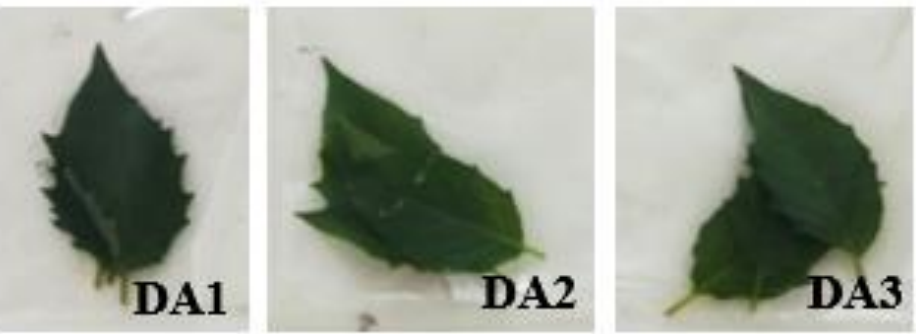

Gambar 1. Sampel daun ciplukan; (DA1) daun ciplukan sampel 1, (DA2) daun ciplukan sampel 2 dan (DA3) daun ciplukan sampel 3.

Tahapan isolasi bakteri endofit daun ciplukan diawali dengan proses sterilisasi permukaan. Sterilisasi permukaan bertujuan untuk menghilangkan kotoran serta mikroorganisme dari permukaan tanaman (Hermawati, 2016). Proses pra sterilisasi dilakukan dengan pencucian sampel daun dengan air mengalir untuk menghilangkan kotoran dan oraganisme epifit yang menempel pada permukaan tanaman (Hafsari \& Isma, 2013). Proses sterilisasi permukaan menggunakan alkohol $70 \%$ dan larutan matrium hipoklorit 5,52\% sebagai desinfektan untuk dekontaminasi permukaan tanaman. Kombinasi larutan alkohol dan natrium hipoklorit merupakan kombinasi yang sesuai karena memiliki aktivitas yang berbeda. Alkohol dapat mendenaturasikan protein dengan cara dehidrasi dan menginaktifkan enzim serta mendenaturasi protein lebih cepat (Rutala et al., 2008). Sedangkan natrium hipoklorit bekerja dengan mengoksidasi secara irreversible gugus sulfihifril pada enzim serta mengganggu fungsi metabolik dari sel bakteri (Rutala et al., 2008). Tahap selanjutnya yaitu 
dilakukan pembilasan dengan aquades steril untuk membersihkan mikroorganisme yang mati (Hafsari \& Isma, 2013), menghilangkan sisa alkohol dan serta $\mathrm{NaOCl}$ yang menempel di permukaan tanaman (Pratiwi, 2015).

Bakteri endofit daun ciplukan mulai menunjukkan pertumbuhan setelah daun ciplukan diinokulasi pada media TSA selama 48 jam. Pernyataan ini didukung oleh Jalgaonwala et al. (2010) yang menyatakan bahwa waktu inkubasi pertumbuhan bakteri endofit minimal 48 jam untuk memastikan bahwa bakteri yang tumbuh merupakan bakteri endofit daun ciplukan. Bakteri endofit yang dihasilkan dari daun ciplukan tumbuh di sekitar medium karena adanya penyebaran cairan serta tumbuh di sekitar sampel. Hal tersebut disebabkan karena bakteri endofit memperoleh nutrien dari media pertumbuhan. Media pertumbuhan yang digunakan untuk mengisolasi bakteri endofit pada penelitian ini adalah media TSA. Media ini merupakan media yang sudah diperkaya yang terdiri atas casein, soy meal, sodium chlorid dan agar. Bakteri endofit dapat hidup pada media TSA dikarenakan sifat media yang kompleks dan memiliki komposisi yang mirip seperti kondisi di dalam tanaman. Selain itu, penambahan larutan kandistatin $0,02 \%$ pada media TSA bertujuan untuk mengoptimalkan hasil isolasi bakteri endofit (Kumala \& Siswanto, 2007 dalam Purwanto dkk., 2014). Kandistatin merupakan antifungi yang berfungsi untuk menghambat pertumbuhan jamur dalam medium TSA (Djajusman dkk., 2014).

Berdasarkan hasil penelitian, bakteri endofit yang berhasil diisolasi dari daun ciplukan sebanyak 8 bakteri endofit yaitu 5 isolat dari (DA1) dan 3 isolat dari (DA2) (Tabel 1). Sedangkan pada DA3 tidak menunjukkan adanya petumbuhan bakteri endofit. Menurut Yandila dkk. (2018), jumlah populasi bakteri endofit pada suatu jaringan tanaman berbedabeda. Hal tersebut disebabkan karena populasi bakteri endofit dipengaruhi oleh jenis jaringan, waktu pengambilan sampel dan umur tanaman (Yandila dkk., 2018). Keberadaan bakteri endofit pada tanaman muda lebih banyak dibagian akar sehingga dapat memacu pertumbuhan dan meningkatkan perkembangan tanaman terutama pada fase vegetatif (Puspita dkk., 2018). Hal tersebut disebabkan karena bagian akar merupakan jalan utama bagi bakteri endofit untuk masuk ke dalam jaringan tanaman. Bakteri endofit akan menyebar ke seluruh bagian tanaman pada saat tanaman sudah dewasa yaitu pada fase generatif (Puspita dkk., 2018). Hal ini disebabkan oleh adanya aliran produk fotosintesis yang berasal dari daun ke seluruh bagian tanaman melalui floem, sehingga dapat dimanfaatkan oleh bakteri endofit sebagai sumber nutrisi (Lathifah, 2017).

Tabel 1. Populasi dan morfologi koloni isolat bakteri endofit daun ciplukan

\begin{tabular}{ccccc}
\hline Kode & \multicolumn{4}{c}{ Morfologi Koloni } \\
\cline { 2 - 5 } Isolat & Warna Koloni & Bentuk & Elevasi & Tepian \\
\hline DA1 (1) & Kuning & Bulat & Cembung & Mulus \\
DA1 (2) & Krem & Bulat & Cembung & Mulus \\
DA1 (3) & Orange & Bulat & Cembung & Mulus \\
DA1 (4) & Putih & Bulat & Cembung & Mulus \\
DA1 (5) & Orange & Bulat & Cembung & Mulus \\
DA2 (1) & Orange Bening & Bulat & Datar & Mulus \\
DA2 (2) & Krem & Bulat & Cembung & Mulus \\
DA2 (3) & Kuning & Bulat & Cembung & Mulus \\
\hline
\end{tabular}

Keterangan : DA1=daun ciplukan sampel 1, DA2=daun ciplukan sampel 2

Isolat bakteri endofit yang diperoleh dari daun ciplukan diamati secara makroskopik untuk melihat perbedaan dari setiap isolat. Koloni bakteri endofit yang diperoleh dari bagian daun ciplukan memiliki morfologi koloni yang bervariasi yaitu memiliki morfologi dengan warna krem, orange, orange bening, krem bening, kuning dan putih (Tabel 1). Sedangkan bentuk koloni bakteri endofit yaitu bulat dengan elevasi cembung dan datar. Tepian koloni 
bakteri endofit menunjukkan bentuk tepian yang mulus. Karakteristik morfologi yang beragam dari masing-masing koloni berhubungan dengan genus dan spesies dari masing-masing bakteri.

Menurut Bhore and Sathisha (2010), keragaman jenis bakteri endofit pada suatu tanaman dipengaruhi oleh kondisi pertumbuhan tanaman. Tanaman dengan jenis yang sama dapat memiliki jenis bakteri endofit yang berbeda. Hal tersebut dikarenakan beberapa tanaman memiliki bakteri endofit yang spesifik dan khas menghuni tanaman tersebut (Bhore and Sathisha, 2010). Warna koloni bakteri yang bervariasi disebabkan karena adanya pigmen pigmen karatenoid, antosianin, melanin, tripitilmethenes dan fenazin yang dihasilkan bakteri endofit. Keberadaan pigmen pada suatu bakteri dapat dilihat pada warna koloni bakteri (Savitri, 2006 dalam Safrida dkk., 2012).

\section{Uji Aktivitas Antibakteri}

Uji aktivias antibakteri dilakukan pada kedelapan isolat bakteri endofit untuk mengetahui isolat bakteri yang potensial dalam menghambat pertumbuhan bakteri patogen. Isolat bakteri endofit diuji aktivitas antibakteri terhadap bakteri gram positif (S.aureus) dan gram negatif (E.coli). Pemilihan dua jenis bakteri patogen dalam penelitian ini berdasarkan alasan bahwa bakteri-bakteri tersebut lazim digunakan sebagai model untuk pengujian senyawa aktif baru dan bersifat patogen bagi manusia. Bakteri E.coli dapat menimbulkan infeksi saluran kencing, diare dan meningitis (Nugraheni, 2019). Selain itu, kedua bakteri patogen juga digunakan untuk membandingkan kemampuan dari dua jenis bakteri yang berbeda yaitu bakteri gram negatif dan gram positif.

Tabel 2. Diameter zona hambat yang terbentuk pada uji aktivitas antibakteri isolat bakteri endofit terhadap bakteri patogen.

\begin{tabular}{ccc}
\hline Kode Isolat & \multicolumn{2}{c}{ Diameter Zona Hambat $(\mathbf{m m})$} \\
\cline { 2 - 3 } & $\begin{array}{c}\text { Zona Hambat } \\
\text { (S.aureus) }\end{array}$ & $\begin{array}{c}\text { Zona Hambat } \\
(\text { E.coli })\end{array}$ \\
\hline DA1 (1) & $1 \mathrm{~mm}$ & $2 \mathrm{~mm}$ \\
DA1 (2) & $1 \mathrm{~mm}$ & - \\
DA1 (3) & $2 \mathrm{~mm}$ & - \\
DA1 (4) & $2 \mathrm{~mm}$ & $2 \mathrm{~mm}$ \\
DA1 (5) & $0,5 \mathrm{~mm}$ & - \\
DA2 (1) & $1 \mathrm{~mm}$ & - \\
DA2 (2) & $2 \mathrm{~mm}$ & - \\
DA2 (3) & $0,5 \mathrm{~mm}$ & - \\
Kontrol & $30 \mathrm{~mm}$ & $20 \mathrm{~mm}$ \\
Positif & \multicolumn{2}{|l}{} \\
\hline Keterangan : DA1=daun ciplukan sampel 1, DA2=daun ciplukan sampel 2
\end{tabular}

Berdasarkan hasil pengujian aktivitas antibakteri, sebanyak 8 isolat bakteri endofit daun ciplukan mampu menghambat pertumbuhan bakteri S.aureus dengan diameter zona hambat berkisar antara 0,5 hingga $2 \mathrm{~mm}$. Sedangkan bakteri endofit yang mampu menghambat pertumbuhan bakteri E.coli hanya dua isolat yaitu DA1 (1) dan DA1 (4) dengan diameter zona hambat sebesar $2 \mathrm{~mm}$ (Tabel 2). Diameter zona hambat yang dihasilkan isolat bakteri endofit termasuk dalam kategori lemah yaitu berkisar antara $0,5 \mathrm{~mm}$ hingga $2 \mathrm{~mm}$. Isolat bakteri endofit DA1 (1) dan DA1 (4) mampu menghambat pertumbuhan kedua bakteri patogen. Hal tersebut menandakan bahwa senyawa antibakteri yang dihasilkan oleh bakteri endofit DA1 (1) dan DA1 (4) memiliki spektrum yang luas. Bakteri endofit dikatakan memiliki spektrum yang luas apabila dapat menghambat pertumbuhan bakteri gram negatif dan gram positif (Pratiwi, 2015).

Terbentuknya zona hambat di sekitar koloni isolat bakteri endofit mengindikasikan adanya senyawa antibakteri yang mampu menghambat pertumbuhan bakteri patogen. 
Keragaman zona hambat yang dihasilkan bakteri endofit dipengaruhi oleh beberapa faktor antara lain kecepatan difusi senyawa antibakteri ke dalam media serta interaksinya dengan bakteri patogen, kecepatan pertumbuhan bakteri endofit, dan sensitifitas bakteri patogen terhadap senyawa antibakteri (Setyati dkk., 2016). Selain itu, beberapa faktor lain yang juga dapat mempengaruhi terbentuknya zona hambat yaitu perbedaan struktur sel bakteri patogen, dan perbedaan jenis dan jumlah senyawa antibakteri yang dihasilkan bakteri endofit (Kusumawati dkk., 2014). Penelitian serupa juga dilakukan oleh Kusumawati dkk. (2014), dimana sebanyak 13 bakteri endofit yang diperoleh dari tanaman miana mampu menghambat pertumbuhan bakteri E.coli dengan diameter zona hambat berkisar antara 1-3 mm dan sebanyak 15 isolat bakteri endofit mampu menghambat pertumbuhan bakteri S.aureus dengan diameter zona hambat antara 1,5-7 mm (Kusumawati dkk., 2014).

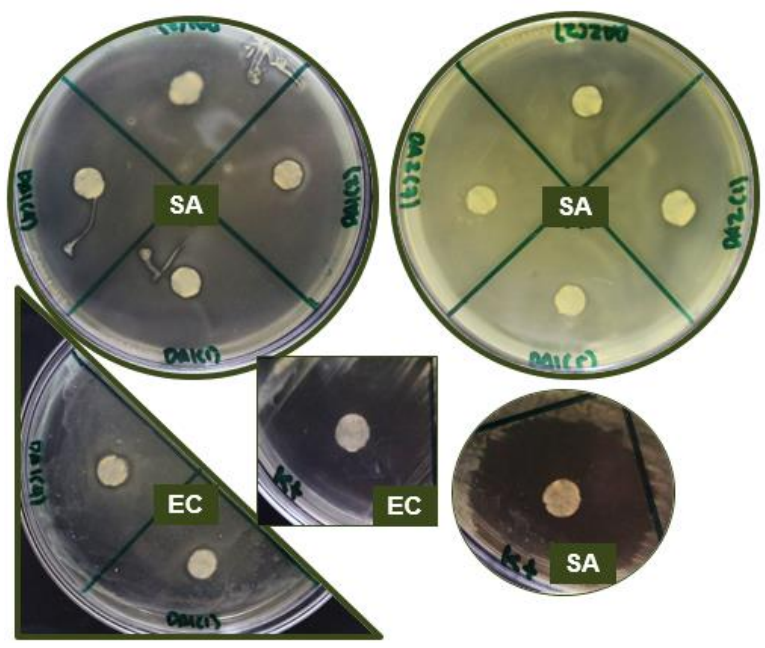

Gambar 2. Zona hambat isolat bakteri endofit terhadap S.aureus dan E.coli. (SA) : S.aureus dan (EC) : E.coli. Isolat dengan kode DA1 (1-8) menunjukkan zona hambat terhadap S.aureus dan isolat DA1(1) dan DA2(2) terhadap E.coli serta kontrol positif kloramfenikol (K+) terhadap E.coli dan S.aureus

Isolat bakteri endofit yang memiliki populasi tertinggi dalam menghambat pertumbuhan bakteri patogen yaitu sebanyak 8 isolat bakteri endofit terhadap bakteri $S$. aureus. Sedangkan 2 isolat hanya mampu menghambat bakteri E.coli (Gambar 2). Adanya perbedaan jumlah bakteri yang mampu menghambat bakteri patogen dikarenakan adanya perbedaan zona hambat yang dihasilkan pada bakteri Gram positif maupun Gram negatif. Terbentuknya zona hambat yang berbeda pada masing-masing bakteri endofit terhadap bakteri patogen disebabkan jumlah bakteri patogen yang berlebihan. Jumlah bakteri patogen yang berlebihan menyebabkan senyawa metabolit sekunder yang dihasilkan bakteri endofit tidak signifikan terhadap pertumbuhan bakteri patogen (Fithriyah, 2015). Selain itu, perbedaan struktur dinding sel pada kedua bakteri patogen juga menyebabkan adanya perbedaan sensivitas bakteri patogen terhadap senyawa antibakteri (Sari, 2018).

Bakteri Gram positif cenderung lebih sensitif terhadap senyawa antibakteri. Hal tersebut dikarenakan struktur dinding sel bakteri Gram positif lebih sederhana dibandingkan struktur dinding sel bakteri Gram negatif. Perbedaan struktur dinding sel pada kedua bakteri patogen tersebut dapat memudahkan senyawa antibakteri untuk masuk ke dalam sel bakteri gram positif secara maksimal (Fithriyah, 2015). Struktur dinding sel bakteri Gram positif terdiri dari 2-3 lapis membran sitoplasma yang terusun dari asam teikoat dan asam teikourenik berupa polimer yang larut dalam air sehingga lebih mudah untuk ditembus senyawa antibakteri dari luar (Vitasari, 2012). Sedangkan struktur dinding sel bakteri Gram negatif memiliki susunan dinding sel yang lebih kompleks karena mengandung lebih sedikit peptidoglikan, tetapi di luar lapisan tersebut terdapat tiga polimer yaitu lipoprotein, selaput luar dan lipopolisakarida (Jawetz et al.,2005 dalam Sari, 2018). 
Bakteri endofit yang mampu menghasilkan aktivitas antibakteri pada bakteri patogen dikarenakan adanya senyawa metabolit sekunder yang pada daun ciplukan yang berpotensi sebagai antibakteri. Aktivitas antibakteri dalam menembus struktur dinding sel bakteri yaitu dengan menghambat sintesis peptidoglikan yang mengaktivasi enzim lisis serta menghasilkan lisis pada lingkungan yang isotonik (Sari, 2018). Menurut Masfufah dkk. (2019), bakteri endofit B.E2 daun tanaman sukun (Artocarpus altilis) mampu menghasilkan senyawa metabolit sekunder golongan flavonoid, alkaloid dan saponin. Ketiga senyawa tersebut mampu menghambat pertumbuhan bakteri Gram negatif maupun positif dikarenakan memiliki kemampuan sebagai antibakteri (Masfufah dkk., 2019).

Salah satu mekanisme senyawa antibakteri dalam menghambat pertumbuhan bakteri patogen yaitu dengan cara mendenaturasi protein sel bakteri (Rijayanti, 2014). Bakteri patogen akan membentuk ikatan hidrogen dengan senyawa antibakteri. Ikatan hidrogen yang terbentuk antara fenol dan protein akan mengakibatkan struktur protein bakteri menjadi rusak. Ikatan hidrogen tersebut kemudian akan mempengaruhi permeabilitas dinding sel bakteri dan membran sitoplasma karena tersusun dari protein. Permeabilitas dinding sel dan membran sitoplasma yang terganggu akan menyebabkan ketidakseimbangan makromolekul dan ion dalam sel bakteri (Rijayanti, 2014). Hal tersebut menyebabkan struktur lapisan dinding sel bakteri tidak terbentuk secara utuh dan sel tidak dapat menahan tekanan osmotik yang tinggi sehingga akan mengalami lisis bakteri (Isniyetty, 2010).

Koramfenikol merupakan salah satu antibiotik yang digunakan sebagai pembanding untuk melihat potensi bakteri endofit antibiotik yang memiliki potensi sebagai antibakteri. Menurut Wibowo \& Yuliani (2015), kloramfenikol merupakan antibiotik yang memiliki spektrum luas dan tingkat sensivitas yang tinggi terhadap bakteri Gram positif maupun Gram negatif. Diameter zona hambat yang dihasilkan antibiotik kloramfenikol termasuk dalam kategori sangat kuat terhadap bakteri Gram positif yaitu $S$. aureus dengan diameter diameter zona hambat $30 \mathrm{~mm}$ dan kategori penghambatan kuat dengan diameter $20 \mathrm{~mm}$ terhadap bakteri Gram negatif yaitu bakteri E. coli. Berdasarkan perbedaan diameter zona hambat yang dihasilkan dapat dikatakan bahwa antibiotik kloramfenikol memiliki aktivitas antibakteri spektrum luas dengan kekuatan daya hambat yang tinggi dalam menghambat dan membunuh bakteri, baik kelompok Gram positif maupun Gram negatif. Menurut Levinson (2004 dalam Alviana, 2016), antibiotik kloramfenikol mampu mengikat subunit ribosom 50S sel bakteri target dan menghalangi aktivitas enzim peptidyltransferase sehingga terjadi hambatan pembentukan ikatan peptida dan biosintesis protein. Antibiotik kloramfenikol jug dapat menghambat pertumbuhan bakteri gram positif secara maksimal karena memiliki struktur dinding sel yang sederhana dibandingkan dengan bakteri gram negatif (Vitasari, 2012).

\section{SIMPULAN}

Bakteri endofit berhasil diisolasi dari daun ciplukan dan diperoleh sebanyak 8 isolat bakteri endofit. Berdasarkan uji aktivitas antibakteri, diperoleh 8 isolat isolat bakteri endofit yang memiliki potensi sebagai antibakteri terhadap bakteri S.aureus dan 2 isolat terhadap bakteri E.coli. Isolat DA1 (3), DA1 (4) dan DA2 (2) memiliki daya hambat tertinggi terhadap bakteri S.aureus. Sedangkan isolat yang memiliki daya hambat tertinggi terhadap bakteri E.coli yaitu DA1 (1) dan DA1 (4). Isolat bakteri endofit DA1 (1) dan DA1 (4) mampu menghambat pertumbuhan kedua bakteri patogen dengan diameter zona hambat berkisar antara 1-2 $\mathrm{mm}$.

\section{SARAN}

Penelitian lebih lanjut perlu dilakukan untuk mengidentifikasi spesies isolat bakteri endofit yang potensial dalam menghambat pertumbuhan bakteri patogen. Peneliti selanjutnya perlu melakukan pengujian lanjut untuk mengisolasi dan mengidentifikasi senyawa yang dihasilkan oleh isolat bakteri endofit. 


\section{REFERENCE}

Alkautsari, L., Widiana, R., \& Indriati, G. (2015). Uji aktivitas antibakteri ekstrak daun ciplukan (Physalis Minima Linn.) terhadap pertumbuhan bakteri Salmonella Sp. E-Jurnal, Padang.

Alviana, N. (2016). Uji efektivitas antibakteri ekstrak etanol daun krisan (Chrysanthemum morifolium Syn. Dendrathema grandiflora) terhadap S. aureus dan E. coli. Skripsi. Fakultas Teknobiologi. Universitas Atma Jaya Yogyakarta. Yogyakarta.

Amaria, W., Kasim, N. N \& Munif, A. (2019). Kelimpahan populasi bakteri filosfer, rizosfer, dan endofit tanaman kemiri sunan (Reutealis Trisperma (Blanco) Airy Shaw), serta potensinya sebagai agens biokontrol. Journal TABARO, 3(1), 305-317.

Bergey's. (2005). Manual of systematic bacteriology. Department of Microbiology and Molecular Genetics: Michigan State University.

Bhore, S. J and Sathisha, G. (2010). Screening of endophytic colonizing bacteria for cytokininlike compounds: crude cell-free broth of endophytic colonizing bacteria is unsuitable in cucumber cotyledon bioassay. World Journal of Agricultural Sciences. Sci, 6(4), 345-352.

Compant, S., Clément, C., \& Sessitsch, A. (2010). Plant growth-promoting bacteria in the rhizo- and endosphere of plants: Their role, colonization, mechanisms involved and prospects for utilization. Soil Biology and Biochemistry, 42(5), 669-678. https://doi.org/10.1016/j.soilbio.2009.11.024

Desriani., Safira, U. M., Bintang, M., Rivai, A., \& Lisdiyanti, P. (2014). Isolasi dan Karakterisasi Bakteri Endofit dari Tanaman Binahong dan Katepeng China. Jurnal Kesehatan Andalas, 3(2), 89-93. https://doi.org/10.25077/jka.v3i2.33

Djajusman, S. K., Tedjosasongko, U., \& Irmawati, I. (2014). Daya hambat xylitol dan nistation terhadap pertumbuhan Candida albicans (in vitro) (Inhibition effect of xylitol and nistatin combination on Candida albicans growth (in vitro)). Dental Journal (Majalah Kedokteran Gigi), 47(3), 164-167. https://doi.org/10.20473/j.djmkg.v47.i3.p

Fithriyah, N. L. (2015). Isolasi dan identifikasi bakteri endofit dari rumput kebar (Biophytum sp.) sebagai penghasil senyawa antibakteri terhadap bakteri E.coli dan S.aureus. Skripsi. Fakultas Sains dan Teknologi. Universitas Islam Negeri Maulana Malik Ibrahim. Malang.

Hafsari, A. R \& Isma, A. (2013). Isolasi dan identifikasi kapang endofit dari tanaman obat surian (Toona sinensis). Artikel edisi agustus, 7(2), 175-191.

Hermawati, L. (2016). Uji aktivitas antibakteri isolat kapang endofit dari daun tanaman paku daun kepala tupai (Drynaria quercifolia (L.) J. Smith) terhadap E.a coli, Salmonella typhi, S. aures dan Bacillus subtilis. Skripsi. Fakultas Kedokteran dan Ilmu Kesehatan. Universitas Islam Negeri Syarif Hidayatullah Jakarta. Jakarta.

Irdawati., Linda, A., \& Fitri, A. (2017). Isolation and Activity Test of Antimicrobial Endophytic Bacteria from Leaf Salam (Syzygium polyanthum Wight). Bio Science, 1(2), 62-69.

Isniyetty. (2010). Isolasi dan uji antibakteri flavonoid dari daun ciplukan (Physalis Minima Linn). EKSAKTA, 2(1), 95-102.

Jalgaonwala, R. E, Mohite, B. V, and Mahajan, R. T. (2010). Evaluation of endophytes for their antimicrobial activity from indigenous medicinal plants belonging to north maharashtra region india . Int. J. on Pharm and Biomed Res, 1(5), 136- 141.

Kementerian Perdagangan (Kemendag) RI. (2014). Warta ekspor obat herbal tradisional. Kementerian Perdagangan Republik Indonesia. Jakarta.

Kumala, S \& Ainun, A. P. (2014). Efek Antimikroba dari Kapang Endofi t Ranting Tanaman Biduri. Jurnal Farmasi Indonesia, 7(2), 111-120.

Kusumawati, D. E., Pasaribu, F. H., \& Bintang, M. (2014). Aktivitas antibakteri isolat bakteri endofit dari tanaman miana (Coleus Scutellariodes [L.] Benth.) terhadap S. aureus dan E. 
coli. Current Biochemistry, 1(1), 45 - 50.

Lathifah, A. (2017). Isolasi, karakterisasi dan uji antimikroba bakteri endofit Lokio (Allium chinense G. Don). Tesis. Sekolah Pascasarjana. Institut Pertanian Bogor. Bogor.

Masfufah., Puji, A., \& Afghani, J. (2019). Aktivitas antibakteri dari isolat bakteri endofit B.E2 daun tanaman sukun (Artocarpus altilis) terhadap S. typhimurium dan S. aureus. Jurnal Kimia Khatulistiwa, 8(1), 79-85.

Nugraheni, I. A. (2019). Deteksi Escherichia coli dan Salmonella pada jamu kunir asem di Daerah Gamping, Sleman, Yogyakarta. Jurnal Health Of Studies, 3(2), 40-50.

Nursanty, R \& Suhartono. (2012). Isolasi karakterisasi dan uji antimikroba bakteri endofit asal tumbuhan johar (Cassia Siamea Lamk.). Jurnal Ilmiah Pendidikan Biologi, Biologi Edukasi, 4(1), 7-10.

Nursulistyarini., Fenni \& Ainy, E. Q. (2013). Isolasi dan identifikasi bakteri endofit penghasil antibakteri dari daun tanaman binahong (Anredera Cordifolia (Ten) Steenis). Seminar Nasional Xi Pendidikan Biologi. Fakultas Kedokteran Ilmu Pendidikan. Universitas Negeri Surakarta. Surakarta.

Oktavia, N., \& Sri, P. (2018). Isolasi dan uji antagonisme bakteri endofit tapak dara (Catharanthus Roseus, L.) terhadap bakteri E. coli dan S. aureus. Berkala Bioteknologi, 1(1), 6-12.

Osho, A., Adetunji, T., Fayemi S. O., and Moronkola, D. O. (2010). Antimicrobial activity of essential oils of Physalis angulata. L. Journal Tradit Complement Altern Med, 7(4), 303306.

Pratiwi, B. E. (2015). Isolasi dan skrining fitokimia bakteri endofit dari daun rambutan (Nephelium lappaceum L.) yang berpotensi sebagai antibakteri. Skripsi. Fakultas Kedokteran Dan Ilmu Kesehatan. Universitas Islam Negeri Syarif Hidayatullah. Jakarta.

Purwanto, U. M. S., Fachriyan, H. P., \& Maria, B. (2014). Isolasi bakteri endofit dari tanaman sirih hijau (Piper Betle L.) dan potensinya sebagai penghasil senyawa antibakteri. Current Biochemistry, 1(1), $51-57$.

Puspita, F., Sukemi, I. S., \& Jenny, M. (2018). Uji Beberapa Konsentrasi Bakteri Bacillus sp. Endofit untuk Meningkatkan Pertumbuhan Bibit Kakao (Theobroma cacao L.). Jurnal Agronomi Indonesia, 46(3), 322-327.

Putri, M. F., Fifendy, M., \& Putri, D. H. (2018). Diversitas bakteri endofit pada daun muda dan tua tumbuhan andaleh (Morus macroura miq.). Eksakta, 19(1), 125-130.

Rijayanti, R. P. (2014). Uji aktivitas antibakteri ekstrak etanol daun mangga bacang (mangifera foetida l.) terhadap staphylococcus aureus secara in vitro. Naskah Publikasi. Fakultas Kedokteran. Universitas Tanjungpura. Tanjungpura.

Rutala, W. A., David, J. W., and Healthcare Infection Control Practices Advisory Committe. (2008). Guideline for disinfection and sterilization in helatcare facilities. Department of Health and Human Services, USA.

Ryan, R. P., Kieran, G., Ashley, F., David, J. R and David, N. D. (2008). Bacterial endophytes: recent developments and applications. FEMS Microbiol Lett, 27(8), 1-9.

Safrida, Y. D., Cut, Y \& Cut, N. D. (2012). Isolasi dan karakterisasi bakteri berpotensi probiotik pada ikan kembung (Rastrelliger sp.). Depik, 1(3), 200-203.

Sari, N. I. P. (2018). Isolasi, karakterisasi dan aktivitas antimikroba bakteri endofit pada lamun Thalassia hemprichii terhadap pertumbuhan bakteri Bacillus cereus, P. aeruginosa dan jamur Candida albicans. Artikel Penelitian. Fakultas Keguruan dan Ilmu Pendidikan. Universitas Mataram.

Setyati, W. A., Ahmad, S. H., Subagyo., Ali, R., Nirwani, S., \& Rini, P. (2016). Skrining dan seleksi bakteri simbion spons penghasil enzim ekstraseluler sebagai agen bioremediasi bahan organik dan biokontrol vibriosis pada budidaya udang. Jurnal Kelautan Tropis, 19(1), 11-20. 
Sulistiyani, T. R., \& Puspita, L. (2016). Keragaman bakteri endofit pada tanaman Curcuma heyneana dan potensinya dalam menambat nitrogen. Widyariset, 2(2), $106-117$.

Susilowati, R. (2017). Analisis karakter morfologi, anatomi, dan struktur sekretori tanaman ciplukan (Physalis angulata L.). Skripsi. Fakultas Matematika Dan Ilmu Pengetahuan Alam. Institut Pertanian Bogor. Bogor.

Vitasari, O. N. (2012). Uji aktivitas antibakteri ekstrak etanol daun ciplukan terhadap S. aureus dan P. aureginosa. Skripsi. Fakultas Matematika dan Ilmu Pengetahuan Alam. Universitas Sebelas Maret. Surabaya.

Wibowo, T. C \& Yuliani, R. (2015). Aktivitas antibakteri ekstrak etanol buah pare (Momordica charantia L.) terhadap bakteri E.coli dan S.aureus Multiresisten antibiotik beserta uji bioautografinya. Naskah Publikasi. Fakultas Farmasi. Universitas Muhammadiyah Surakarta. Surakarta.

Wondal, B., Elvy, L. G., Veibe, W., Stenly, W., Sandra, O. T and Ferdinand, F. T. (2019). Isolasi bakteri laut dari Perairan Malalayang Sulawesi Utara. Jurnal Pesisir dan Laut Tropi, 7(3), 183-189.

Yandila, S., Dwi, H. P., \& Mades, F. (2018). Kolonisasi bakteri endofit pada akar tumbuhan andaleh (Morus macroura Miq.). Bio-site, 4(2), $61-67$. 